\title{
Gender and sexual diversity - changing paradigms in an ever-changing world
}

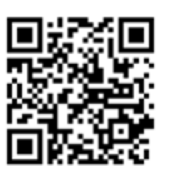

Enshrined in the Bill of Rights of South Africa's Constitution $^{[1]}$ are a number of rights that affirm the democratic values of human dignity, equality and freedom. Section 9(3) states that 'The state may not unfairly discriminate directly or indirectly against anyone on one or more grounds, including race, gender, sex, pregnancy, marital status, ethnic or social origin, colour, sexual orientation, age, disability, religion, conscience, belief, culture, language and birth.'

Despite these rights, which are also embodied in policy and law at the highest levels internationally, lesbian, gay, bisexual, transgender and intersex (LGBTI) people are subjected to discrimination, abuse, violence and even death because they do not fit into the expectations of what certain sectors of society consider to be the 'norm'.

In his book A Social Justice Advocate's Handbook: A Guide to Gender, Sam Kellerman ${ }^{[2]}$ defines four elements that together contribute to gender and sexual diversity:

1. Biological sex (which I also refer to as physical sex)

2. Gender identity (which I also refer to as psychological sex)

3. Sexual orientation

4. Gender expression (which is a manifestation of 1,2 and 3 ).

All possible permutations of the above four elements in combination are found in all societies and to varying degrees. Gender is defined by the World Health Organization (WHO) as 'socially constructed roles, behaviors, activities, and attributes that a given society considers appropriate for men and women'. It is therefore society that establishes gender norms, which in turn determine the extent to which variations in gender have the freedom to be expressed.

As health professionals confronted with people who seek our help, we might ask at what point variations in biological structure and function per se require intervention. Variations require intervention when they lead to:

1. Distress or suffering that is the consequence of the variant itself and not the consequence of judgmental factors emanating from the external environment

2. Significant impairment of personal, social, occupational or other important areas of life as a consequence of 1 above, and 3. Death.

In the context of the present discussion on gender and sexual diversity, some people who do not fit into the generally accepted 'norm' do suffer and do experience significant impairment of personal, social, occupational or other important areas of their lives. Yet this is due in large part to the inability of society to embrace diversity, and in the process society's tendency to marginalise people who do not conform. Although the inability to have children may be a cause of distress, several mechanisms are in place that allow the perceived limitation on parenthood to be overcome.

\section{Development of physical and psychological sex}

It is well established that fetal androgen signalling strongly influences sexual development. Sexual differentiation of the gonads (ovary, testis), internal reproductive organs and external genitalia occurs in the first half of pregnancy, i.e. between 9 and 15 weeks of gestation, with the $\mathrm{Y}$ chromosome (SRY gene) being required for male development. Sexual differentiation of the brain starts in the second half of pregnancy. Testosterone masculinises the fetal brain, whereas absence of the dominant effect of this hormone results in a female brain. A recent study found that 'a primary effect of gonadal steroids in the highly sexually dimorphic preoptic area (POA) is to reduce activity of DNA methyltransferase (Dnmt) enzymes, thereby decreasing DNA methylation and releasing masculinizing genes from epigenetic repression ... [The] data show that brain feminization is maintained by the active suppression of masculinization via DNA methylation. ${ }^{\text {[3] }}$

Gender identity is therefore largely programmed into our brains while we are still in the womb. Important to recognise is the fact that the establishment of physical and psychological sex is separated during fetal development, the former occurring in the first trimester and the latter in the second trimester. This provides a window between the two during which environmental influences (for example endocrine disruptors) may affect the alignment between physical and psychological sex. In the event of ambiguous sex at birth (intersex see below), the degree of feminisation/masculinisation of the genitals may not reflect the degree of feminisation/masculinisation of the brain. The interplay between nature (genes and genetics) and nurture (the environment) is at the heart of the debate around what is responsible for gender and sexual diversity. The increasing importance of the intrauterine environment on gene expression (DNA) is being recognised, ${ }^{[4]}$ and is embodied in the rapidly emerging field of epigenetics.

\section{Gender dysphoria and transgenderism} Gender dysphoria, previously known as gender identity disorder, occurs in relation to transsexualism and transgenderism and is a potentially life-threatening condition if unresolved. It is characterised by a dissociation between an individual's biological or physical sex and their gender identity or psychological sex. This leads to social isolation (by choice or through ostracism), low self-esteem and impaired relationships with parents and other family members, and may lead to anxiety, depression, suicidal ideation and suicide attempts. Gender dysphoria requires treatment. This may take several forms including psychological counselling, hormone therapy and gender affirmation/reassignment surgery.

\section{Sexual orientation}

Views on sexual orientation are conditioned by the belief that heterosexuality is the normal default occurrence, also referred to as heteronormativity. The long-held views that sexual orientation in most people is a choice, can be directly transmitted from one individual to another and can be cured if it does not conform to the 'norm' are not substantiated by reliable evidence. ${ }^{[5]}$

\section{Mechanisms governing sexual orientation ${ }^{[6]}$}

The following is known about the molecular basis of homosexuality: 1 . Homosexuality occurs in $\sim 8 \%$ of individuals in most populations. 2. Pedigree and twin studies show that homosexuality is familial.

3. Although there is no consistent evidence for a single major gene contributing to homosexuality, studies performed in the 1990s identified a region in the $\mathrm{X}$ chromosome (Xq28) that is associated with development of homosexuality in males. ${ }^{[7,8]}$ A more recent study ${ }^{[9]}$ has confirmed the importance of this locus, and has 
added a second locus on chromosome 8 . The identification of these loci does not imply that homosexuality is a disorder, nor does it imply that there may be 'mutations' in the 'causative' genes in these regions that remain to be identified. It simply points to chromosomal regions (DNA) that are associated with the determination of sexual orientation.

4. The relatively low concordance in monozygotic twins and the importance of the non-shared environment point to homosexuality as being epigenetically determined. ${ }^{[10]}$

5. In the experimental setting, environmentally induced epigenetic modifications of genes in males that feminise their brains and behaviour can be transgenerationally inherited by their offspring.

6. Homosexual and bisexual behaviour has been observed in many non-human species, and includes sexual activity, courtship, affection, pair bonding, and parenting in same-sex pairs; ${ }^{[11]}$ the motivations for, and implications of, these behaviours have yet to be fully understood.

Conversion or reparative therapy has been advocated for sexual orientation that is not heteronormative. In his book entitled Pilgrim, Pieter Cilliers graphically describes his experiences with conversion therapy and the long-lasting negative consequences thereof. ${ }^{[12]}$ Recently President Obama has called for an end to such therapies for gay, lesbian and transgender youth in the USA. The official White House statement reads as follows: 'Conversion therapy generally refers to any practices by mental health providers that seek to change an individual's sexual orientation or gender identity ... Often, this practice is used on minors, who lack the legal authority to make their own medical and mental health decisions ... The overwhelming scientific evidence demonstrates that conversion therapy, especially when it is practiced on young people, is neither medically nor ethically appropriate and can cause substantial harm. ${ }^{[}{ }^{[13]}$ The Obama statement follows the recommendations of the WHO and a number of major medical institutions. Within the USA, the view on this matter is bipartisan, with several states being either for or against the initiative.

\section{Intersex}

Intersex is the lack of conformity at birth of the reproductive system to what is traditionally considered to be male or female. Children born with intersex may be subjected to 'normalisation' surgery. There are at least two consequences of a decision of this nature, one implicit and the other explicit. The former assumes that intersex is 'wrong', as this is not seen as a variation along a wide spectrum of sexual diversity. The latter denies affected individuals the right to make choices about their own bodies. Since these procedures rarely increase the likelihood that fertility will be improved, and on the contrary may in fact cause infertility, there is little justification for considering the need to 'fix' an intersex child as a medical emergency.

There are several potential short- and long-term consequences of 'normalisation' surgery, ${ }^{[14]}$ including incontinence, scarring, loss of sexual pleasure, pain, lifelong feelings of being abnormal, and depression. Little regard is given to the fact that the individual's gender identity or psychological sex might not correlate with the gender they are to be assigned during surgery, and there is often a lack of adequate informed consent.

The 'Report of the Special Rapporteur on torture and other cruel, inhuman or degrading treatment or punishment' presented at the 22nd session of Human Rights Council of the United Nations General Assembly in 2013 notes that 'Children who are born with atypical sex characteristics are often subject to irreversible sex assignment, involuntary sterilisation, involuntary genital normalising surgery, performed without their informed consent, or that of their parents, "in an attempt to fix their sex" ..., leaving them with permanent, irreversible infertility and causing severe mental suffering. ${ }^{\text {[15] }}$

In line with the changes in the paradigm of managing children with intersex, Malta has recently become the first country to pass a law that will ban normalisation surgery on intersex infants. This is seen as a landmark event in the move away from the use of corrective surgery to 'normalise' intersex children, opening the way to selfdetermination of gender identity.

\section{Conclusion}

Given the complexity of the development of male and female physical and psychological sex and sexual orientation, it is not surprising that there is a great deal of variation along the spectrum of possible manifestations of these three elements. Global trends are seen with regard to attitudes towards LGBTI people, of increased liberalism in some regions and increased conservatism in others. The latter impacts negatively on the health and socioeconomic status of both these individuals and the community at large. The factors that drive these attitudes are complex. While it is recognised that science alone cannot shift prejudice, the discrimination and suffering experienced by LGBTI people will be reduced by embracing diversity.

\section{Michael S Pepper \\ Institute for Cellular and Molecular Medicine, Faculty of Health Sciences, University of Pretoria, South Africa}

\section{Corresponding author: M S Pepper (michael.pepper@up.ac.za)}

1. Constitution of the Republic of South Africa, 1996. http://www.gov.za/documents/constitution/ constitution-republic-south-africa-1996-1 (accessed 28 July 2016).

2. Kellerman, S. A Social Justice Advocate's Handbook: A Guide to Gender. Austin, TX: Impetus Books, 2013:60.

3. Nugent BM, Wright CL, Shetty AC, et al. Brain feminization requires active repression of masculinization via DNA methylation. Nat Neurosci 2015;18:690-697. [http://dx.doi.org/10.1038/ mn.3988]

4. Films for Action. http://www.filmsforaction.org/watch/this-video-dispels-every-nature-vs-nurturemylms for Action. http://www.filmsforaction.org/
myth-youve-ever-heard/ (accessed 12 April 2015).

5. Academy of Science of South Africa. Diversity in Human Sexuality: Implications for Policy in South 5. Academy of Science of South Africa. Diversity in Human Sexuality: Implications for Policy in South
Africa. Pretoria: ASSAf, 2015. http://www.assaf.co.za/wp-content/uploads/2015/06/8-June-Diversityin-human-sexualityl.pdf (accessed 15 June 2015).

6. The Conversation. The science behind a more meaningful understanding of sexual orientation. https:// theconversation.com/the-science-behind-a-more-meaningful-understanding-of-sexual-orientation42641 \#comment_697908 (accessed 15 June 2015).

7. Hamer DH, Hu S, Magnuson VL, Hu N, Pattatucci AM. A linkage between DNA markers on the X chromosome and male sexual orientation. Science 1993;261(5119):321-327.

8. Hu S, Pattatucci AM, Patterson C, et al. Linkage between sexual orientation and chromosome Xq28 in males but not in females. Nat Genet 1995;11(3):248-256.

9. Sanders AR, Martin ER, Beecham GW, et al. Genome-wide scan demonstrates significant linkage for male sexual orientation. Psychol Med 2014;45(7):1379-1388. [http://dx.doi.org/10.1017/ S0033291714002451]

10. Rice WR, Friberg U, Gavrilets S. Homosexuality as a consequence of epigenetically canalized sexual development. Q Rev Biol 2012;87(4):343-368. [http://dx.doi.org/10.1086/668167]

development. Q Rev Biol 2012;87(4):343-368. [http://dx.doi.org/10.1086/668167]
11. Bagemihl B. Biological Exuberance: Animal Homosexuality and Natural Diversity. New York: St Bagemihl B. Biological
Martin's Press, 1999.

12. Cilliers P. Pilgrim. 1st ed. Pretoria: Protea Book House, 2013.

13. We the People. Response to your petition on conversion therapy. https://petitions.whitehouse.gov/ response/response-your-petition-conversion-therapy (accessed 12 April 2015).

14. Ms. Magazine blog. http://msmagazine.com/blog/2013/02/07/un-condemns-normalization-surgeryfor-intersexuality/ (accessed 12 April 2015).

15. United Nations General Assembly. Report of the Special Rapporteur on torture and other cruel, inhuman or degrading treatment or punishment, Juan E. Méndez. http://www.ohchr.org/ Documents/HRBodies/HRCouncil/RegularSession/Session22/A.HRC.22.53_English.pdf?utm_ source $=$ AIC+mailing + list\&utm_campaign $=0940 e 5 a 7 f-$ - \&utm_medium $=$ email (accessed 12 April 2015).

S Afr Med J 2015;105(9):746-747. DOI:10.7196/SAMJnew.8169 